\title{
SCUTIGEROMORPH CENTIPEDES (CHILOPODA: SCUTIGEROMORPHA) OF THE DOMINICAN REPUBLIC, HISPANIOLA
}

\author{
Daniel E. Perez-Gelabert ${ }^{1}$ and Gregory D. Edgecombe ${ }^{2}$ \\ ${ }^{1}$ Department of Entomology, U. S. National Museum of Natural History, Smithsonian Institution, P. O. \\ Box 37012, Washington, D.C. 20013-7012, USA, perezd@si.edu \\ ${ }^{2}$ Department of Earth Sciences, The Natural History Museum, Cromwell Road, London SW7 5DB, UK, \\ g.edgecombe@nhm.ac.uk
}

\begin{abstract}
The fauna of scutigeromorph centipedes in the Dominican Republic is studied for the first time based on a sample of 28 individuals collected at 21 localities in 12 provinces. This sample was found to represent two species: Sphendononema guildingii (Newport, 1844) and Dendrothereua linceci (Wood, 1867), both species with a wide geographic distribution in the Caribbean and tropical America. The widely introduced and synanthropic species of Mediterranean origin Scutigera coleoptrata (Linnaeus, 1758) has never been found in Hispaniola. The scutigeromorph centipedes found as fossilized inclusions in the Dominican amber remain to be properly studied and identified.

Key words: Scutigeras, centipedes, Scutigeromorpha, Chilopoda, fauna, amber fossils, Dominican Republic, Haiti, Caribbean.

Título: Centípedos escutigeromorfos (Chilopoda: Scutigeromorpha) de República Dominicana, La Hispaniola.

\section{RESUMEN}

Se estudia por primera vez la fauna de ciempiés escutigeromorfos de la República Dominicana basados en una muestra de 28 individuos colectados en 21 localidades de 12 provincias. Se encontró que esta muestra representa dos especies: Sphendononema guildingii (Newport, 1844) y Dendrothereua linceci (Wood, 1867), ambas especies con una amplia distribución en el Caribe y América tropical. La especie ampliamente introducida y sinantrópica de origen mediterráneo Scutigera coleoptrata (Linnaeus, 1758) nunca ha sido colectada en La Hispaniola. Los ciempiés escutigeromorfos encontrados como fósiles en el ámbar dominicano todavía no han sido apropiadamente estudiados e identificados.
\end{abstract}

Palabras clave: Scutigeras, ciempiés, Scutigeromorpha, Chilopoda, fauna, fósiles en ámbar, República Dominicana, Haití, Caribe.

\section{INTRODUCTION}

The Scutigeromorpha are the most distinctive of the five orders of centipedes belonging to the class Chilopoda. The unique characteristics of having spiracles positioned dorsally on the tergites, compound eyes, and multisegmented tarsi, places them in a separate subclass, Notostigmophora (Bonato et al., 2011). In general appearance, scutigeromorph centipedes have a uniform morphology characterized by a short (usually $2-3.5 \mathrm{~cm}$, exceptionally up to $8 \mathrm{~cm}$ ) cylindrical body, surrounded by long legs that allow for very rapid locomotion. Although born with only four segments, scutigeromorphs grow by hemianamorphosis to have a fixed adult number of 15 segments, each bearing a pair of legs that increase in length from the anterior to 
the posterior part of the body. The head has a pair of annulated antennae that are more slender than the legs and a pair of compound eyes composed of hundreds of ommatidia. The forcipules (maxillipedes) are flexible along a median hinge and, like all centipedes, have poison that is used in the capture of prey. All scutigeromorphs are active predators of small invertebrates. Reproduction involves a courtship in which male and female circle around each other and fertilization occurs without direct mating through spermatophores that are layed down by the male and picked up by the female. Eggs are laid singly, covered with soil, and abandoned by the mother.

Scutigeromorph specimens are generally scarce in collections because they are infrequently found in the forests or caves and also because the agility of their movements makes them difficult to capture. Despite their homogeneity in general body plan, scutigeromorph species are highly variable morphologically, in size, coloration, and metameric structures such as numbers of tarsomeres and spines on particular podomeres, while at the same time they lack unequivocal diagnostic structures like the male gonopods of Diplopoda, although the shape of the female gonopods is useful (Würmli, 1974; Bolton et al., 2009). This variability caused early scutigeromorph taxonomy, often based on small samples instead of series of specimens, to produce a high number of invalid synonyms. It has been found that scutigeromorph species are more variable and geographically more widely distributed than previously recognized (Würmli, 1974; Edgecombe, 2007). The key criteria for the identification of species are the pigmentation of the head and tergites, shape of female gonopods, and the configuration of spines, spicules and setae on the tergites (Edgecombe \& Cupul-Magaña, 2008).

Scutigeromorphs are known from the fossil record as far back as the Late Silurian, ca 418 million years ago, with additional early records in the Lower and Middle Devonian (Shear et al. 1998; Edgecombe, 2011), and thus are among the earliest terrestrial arthropods. In their ecological preferences, scutigeromorphs are mostly tropical. In present times, their worldwide diversity includes only ca 95 valid species, classified in 26 genera and 3 families (Stoev \& Geoffroy, 2004; Bonato et al., 2011). The family Scutigerinidae is distributed in southern Africa and Madagascar, including three species classified in two genera. The family Pselliodidae is Neotropical and Afrotropical and includes at least three species in a single genus. The largest family is the cosmopolitan Scutigeridae, including all remaining (ca 90) species.

A few scutigeromorph specimens had been recorded early in the $20^{\text {th }}$ century from Haiti. The first and only records of specimens are those given by Verhoeff (1904), who described Pselliophora pulchritarsis from a single female from an unspecified locality in Haiti, and later Chamberlin (1918), who described Pselliophora haitiensis from Grand Riviere, Haiti, based on four specimens, two of them immature. These names subsequently experienced several changes: Chamberlin (1921) proposed the new name Pselliodes for the preoccupied name of Pselliophora Verhoeff, 1904. Later, Würmli (1974) revised the Neotropical Pselliodidae and made both species names (Pselliodes pulchritarsis (Verhoeff, 1904) and Pselliodes haitiensis (Chamberlin, 1918) synonyms of Pselliodes guildingii (Newport, 1844). More recently, Pselliodes Chamberlin, 1921 was proposed to be a junior synonym of Sphendononema Verhoeff, 1904 (Würmli, 2005), and thus the valid name of this species is Sphendononema guildingii (Newport, 1844).

Chamberlin (1918) described two new species from Cuba, namely Pselliophora minor and Pselliophora cubensis. The scutigeromorph centipedes of Cuba were studied by Würmli \& Negrea (1977) based on multiple specimens collected throughout the island. They reported two species, Pselliodes nigrovittata (Meinert, 1886) and Scutigera linceci (Wood, 1867). The review of the Neotropical Pselliodidae by Würmli (1978) and the subsequent generic revision by Würmli (2005) made the two new species of Chamberlin and also Pselliodes nigrovitata synonyms of Sphendononema guildingii (Newport, 1844). The second species, Scutigera linceci, 
has also been involved in some taxonomic flux not yet completely resolved and including many synonyms (Würmli, 1973). Its valid generic assignment is Dendrothereua Verhoeff, 1944 (see Edgecombe \& Giribet, 2009) rather than Scutigera. Conventional practice, following Würmli (1973) and Würmli \& Negrea (1977), recognizes a single species distributed from the southern United States to Panama, Dendrothereua linceci (Wood, 1867). This species name requires fixation with a neotype from its type area in Texas and further molecular sequencing to establish whether the observed long branches that separate populations from distant parts of its geographic range (Edgecombe \& Giribet, 2009) warrant resurrection of synonymized names for cryptic species. Pending this revision, we follow standard usage and apply the specific name $D$. linceci (Wood) to the Dominican material.

Chamberlin (1918) also recorded Pselliophora flavipes (Bollman, 1893) from San Salvador, Bahamas, and Scutigera superba Meinert, 1886 from "West Indies". Both names are also synonyms of Sphendononema guildingii. Peck (1992) reported Scutigera sp. from eight caves in Jamaica, suggesting that it could represent the synanthropic species Scutigera coleoptrata (Linnaeus, 1758). Muchmore (1993) recorded Scutigera linceci for St. John in the Virgin Islands. Lazell (2005) recorded the presence of scutigeromorphs in Guana Island, British Virgin Islands, with the suspicion that these records could represent the same species reported from St. John. Chamberlin (1918) also described the species Gonethella nesiotes from the Cayman Islands and Gonethina grenadensis from Grenada. However, these two monotypic genera are both based on single immature specimens and are of little taxonomic utility.

Obviously the Caribbean fauna of scutigeromorph centipedes has only been subject to sporadic investigation, usually as part of larger efforts to characterize the chilopod fauna of the area. In this paper the fauna of scutigeromorph centipedes of the Dominican Republic, island of Hispaniola is studied for the first time.

\section{OBJECTIVE}

- To characterize the fauna of scutigeromorph centipedes of the Dominican Republic.

\section{MATERIAL AND METHODS}

A faunistic survey was carried out between 2002 and 2004 by the first author and collaborators sampling over 280 localities dispersed throughout the varied geography of the Dominican Republic. Although the primary target of this survey were orthopteroid insects, a total of 23 scutigeromorph specimens were also collected during these expeditions and 5 others were added from the collections of the Museo Nacional de Historia Natural, Santo Domingo (MNHNSD) and the Instituto de Investigaciones Botánicas y Zoológicas (IIBZ) of the Universidad Autónoma de Santo Domingo (UASD). Overall 21 localities from 12 different provinces are represented, located mostly in the central and northern mountains. Nearly all individuals were encountered at night while they were on the vegetation. Scutigeromorphs were captured using an entomological net, immediately preserved in $75 \%$ ethanol and eventually examined under a Leica MZ16A stereoscope. Specimens are deposited in the United States National Museum of Natural History, Smithsonian Institution, Washington, DC (USNM), the MNHNSD and the IIBZ.

\section{RESULTS}

As all previous reports of scutigeromorph centipedes in Hispaniola were based on specimens taken in Haiti, those presented here appear to be the first records of scutigeromorphs specifically from the Dominican Republic. The two species collected have been identified as 
Sphendononema guildingii (Newport, 1844) and Dendrothereua linceci (Wood, 1867). The taxonomic hierarchy for the Hispaniolan specimens and their collection data are as follows:

\author{
Phylum Arthropoda \\ Subphylum Myriapoda \\ Class Chilopoda Latreille, 1817 \\ Subclass Notostigmophora Verhoeff, 1901 \\ Order Scutigeromorpha Pocock, 1895 \\ Family Pselliodidae Kraus, 1955 \\ Genus Sphendononema Verhoeff, 1904
}

Sphendononema guildingii (Newport, 1844)

Figure 1, A and B

Recognition. Body length up to $35 \mathrm{~mm}$. Antennal articles longer than wide. Tergites having most bristles associated with a strong spine, spines mostly half length of bristle; spinulae/spiculae elongate triangular. Lightly pigmented (pale yellow) band on medial part of tergites wide; lateral bands mottled brown. Stoma-saddles strongly vaulted. Female gonopods elongate, with relatively short proarthron and long mesarthron. Male gonopods on first genital segment short, lamelliform; gonopods on second genital segment style-like.

Material examined. 19 DOMINICAN REPUBLIC RD-170 km 8 Cabo Rojo-Aceitillar Rd., Pedernales Prov., 1759.378’N 71³9.001'W, 27 m, 30.vii.2003, D. Perez, R. Bastardo, B. Hierro. (night); 19 DOMINICAN REPUBLIC RD-173 Las Yayitas, Azua Prov., by river, 104 m, 21.xi.2003, 18 29.632'N 7044.253'W, D. Perez, R. Bastardo, A. Francisco. (night); $10^{\top}$ DOMINICAN REPUBLIC RD-174 Las Yayitas, Azua Prov., under forest cover, 21.xi.2003, D. Perez, R., Bastardo, A. Francisco. (night); 1 + DOMINICAN REPUBLIC RD-220 El Callejón de la Loma, Parque Nacional El Choco, Puerto Plata prov., 110 m, 1944.428'N 70²5.459'W, 13.iv.2004, D. Perez, B. Hierro, R. Bastardo. (day/night); 1 \% DOMINICAN REPUBLIC RD-234 Cerro San Francisco, Bánica, Elías Piña prov., 366 m, 1905.284’N 7141.096’W, 21.iv.2004, D. Perez, B. Hierro, R. Bastardo. (night); $1 \delta^{\Uparrow}$ DOMINICAN REPUBLIC San Cristóbal Prov., $\sim 3$ km N La Colonia, Mano Matuey, 7.ix.2008, D. Perez, B. Hierro, R. Bastardo, S. Medrano; 1 i DOMINICAN REPUBLIC RD-051 Loma Guaconejo, Prov. M. T. Sánchez (IIBZ), 1 prob. † Loma Isabel de Torres, Pto. Pta., 29/10/97 (MNHNSD); 1 prob. đ̊ República Dominicana, Prov. Independencia, La Descubierta, Isla Cabritos, UTM 19Q 0212559mE 2047156 mN, 9m, 08-I-2010, G. de los Santos (MNHNSD).

Ecological notes. S. guildingii were collected at night usually while on shrubs of various dry to wet forests in low montane conditions. It appeared that individuals were carrying out most of their hunting on the vegetation.

Previously known distribution. St. Vincent (Chamberlin, 1918), Cuba, Hispaniola, Mexico, Central America and Bolivia, Brazil, Colombia, French Guyana, Guyana, Paraguay, Peru and Venezuela. There is also a doubtful record from California (Stoev \& Geoffroy, 2004).

Family Scutigeridae Leach, 1814

Genus Dendrothereua Verhoeff, 1944

Dendrothereua linceci (Wood, 1867)

Figure 1, C and D 

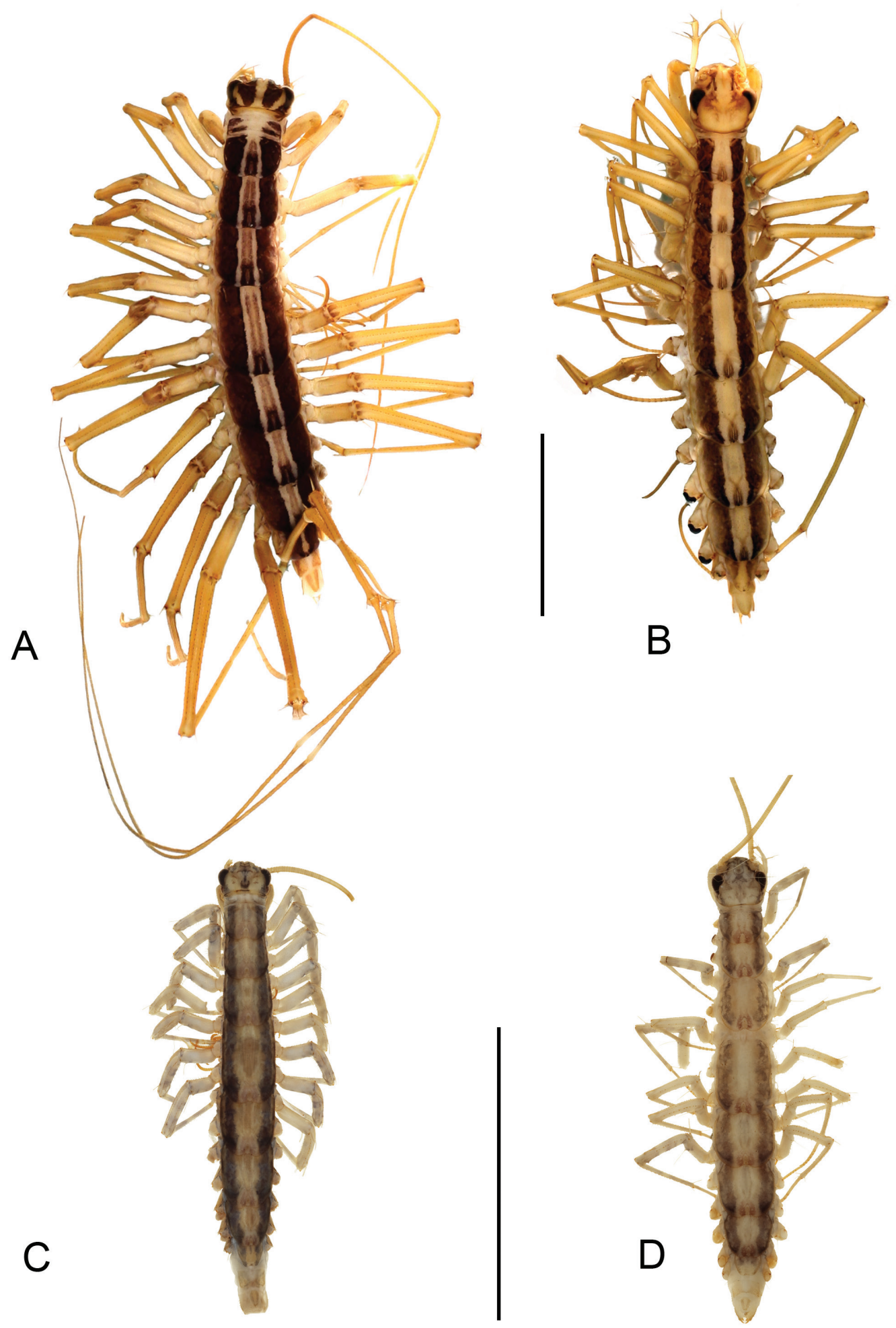

Fig. 1. Photographs of Hispaniolan scutigeromorphs showing variation in body colors. A \& B, Sphendononema guildingii. C \& D, Dendrothereua linceci. Scale approximately $10 \mathrm{~mm}$. 
Recognition. Body length up to $23 \mathrm{~mm}$. Dark bands on lateral parts of tergal plates blue in Dominican material. Spines lacking on tergites; elongate, slender hairs (spiculae) about half length of bristles. Sternites and coxae of posterior trunk segments with dense hairs. Pair of spine-bristles at distal end of tarsus 1 on legs 6-14. Female gonopods 1.9-2.8 times longer than wide; metarthron short, 0.25-0.3 times length of proarthron + mesarthron, claw-like.

Material examined. 1 juvenile sex unknown, DOMINICAN REPUBLIC RD-074 Nizaito, Valle Nuevo, La Vega Prov., (Antiguo Proyecto papas J. D. Guzmán), 2,205 m, 1844.401'N 70³7.588'W, 27.xi.2002, D. Perez, B. Hierro, R. Bastardo. (sunset-night); 19 / 1 juvenile sex unknown, DOMINICAN REPUBLIC RD-076 Way down from Cuevita, Valle Nuevo, La Vega Prov., 2,096 m, $18^{\circ} 46.326^{\prime} N$ 7040.438’W, 28.xi.2002, D. Perez, B. Hierro, R. Bastardo. (night); $1 \delta^{\lambda}$ DOMINICAN REPUBLIC RD-086 Hilltop on way to Palos Grandes, NE of S. J. de Ocoa, 1,437 m, Ocoa Prov., 18³7.871’N 70³0.777’'W, 8.xii.2002, D. Perez, R. Bastardo. (day/night); 2 + + DOMINICAN REPUBLIC RD-087 Way down from Palos Grandes, NE of S. J. de Ocoa, Ocoa Prov., 1,440 m, 18³7.283’N 70³1.481’'W, 8.xii.2002, D. Perez, R. Bastardo. (night); 1 juvenile, DOMINICAN REPUBLIC RD-117 Down from Cuevita, Valle Nuevo, La Vega Prov., 2280 m, 1846.258’N 7040.564’W, 2.iv.2003, D. Perez, R. Bastardo, B. Hierro. (night); 19 DOMINICAN REPUBLIC RD-121 La Jarda (monte arriba), Padre Las Casas, Azua Prov., 1844.167’N 7052.010’W, 5.iv.2003, D. Perez, B. Hierro, S. Medrano, D. Veloz (day); $10^{\lambda}$ DOMINICAN REPUBLIC RD-139 Caseta no. 3, Parque Nacional Sierra de Bahoruco, Independencia Prov., $18^{\circ} 13.720^{\prime} \mathrm{N}$ 71³5.243'W, 1,941 m, 3.vii.2003, D. Perez, R. Bastardo, B. Hierro. (night); $29 q$ juveniles, DOMINICAN REPUBLIC RD-181 Loma Quita Espuela, halfway to peak, 616 m, [Duarte Prov.], 19²0.912'N 7008.941'W, 3.xii.2003, D. Perez, R. Bastardo, A. Marmolejos. (day/night); 3 우 DOMINICAN REPUBLIC RD-184 Trail to peak and Centro SOECI, Pico Diego de Ocampo, Santiago Prov., 918 m, 5.xii.2003, D. Perez, R. Bastardo, A. Marmolejos. (day/night); $20+1$ 1§ DOMINICAN REPUBLIC RD-201 Bejucalito García, 19 km W of Higuey, [La Altagracia Prov.], 1841.182’N 6853.961'W, 19.xii.2003, D. Perez, B. Hierro, R. Bastardo. (night). 1 specimen, Palo de Agua, P. N. Sierra de Bahoruco, 231996 2015021, 1806 msnm, 11:50 am, C. Marte, R. Ortíz (MNHNSD); 1 specimen, M. A. Pinar Parejo, Estación \#VIII, [Valle Nuevo, Prov. La Vega], 10/07/98, col. D. Veloz, S. Navarro (T.A.) (MNHNSD).

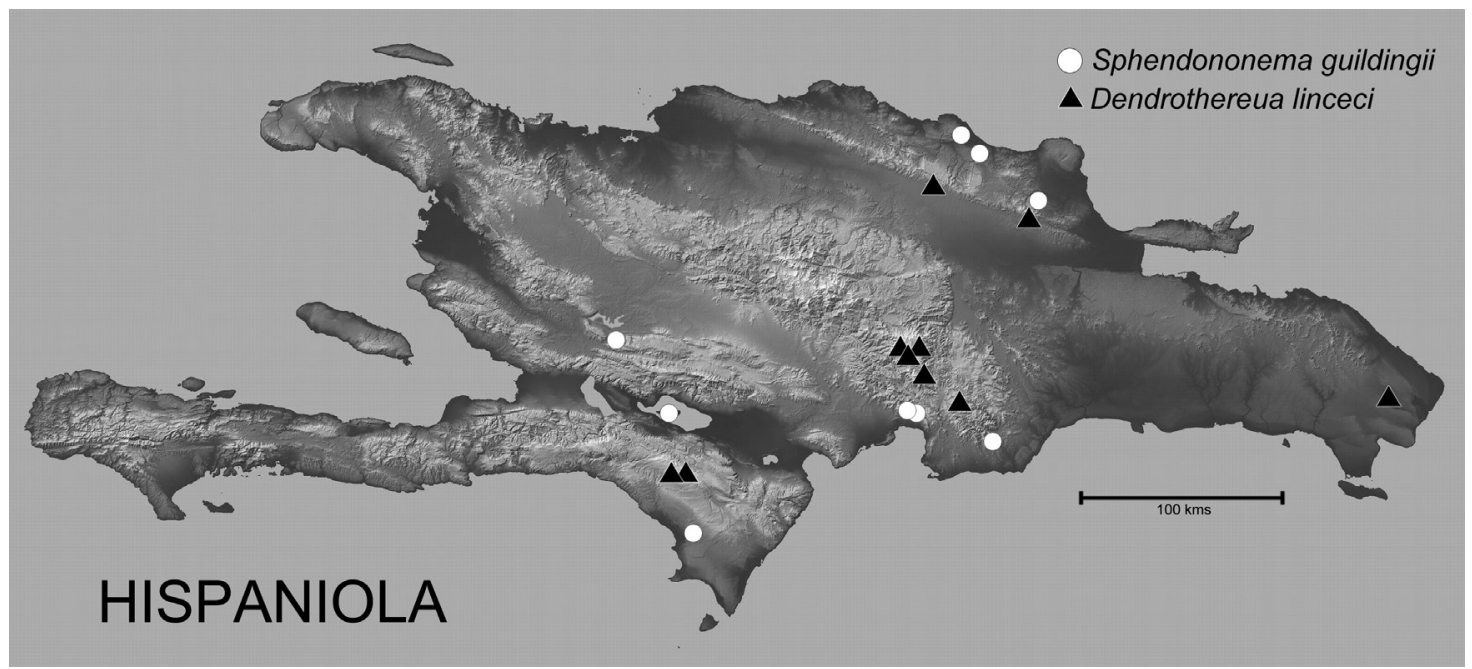

Fig. 2. Distribution of collection localities in the Dominican Republic. White circles, Sphendononema guildingii. Black triangles, Dendrothereua linceci. 
Ecological notes. In general D. linceci was collected at higher elevations, being particularly abundant in Valle Nuevo, an elevated mesa generally situated at over 2,000 m, but it was also collected at a low locality (Bejucalito García, near Higüey) in the eastern plains of the island.

Previously known distribution. Costa Rica, Cuba, El Salvador, USA, Granada, Guatemala, Honduras, Mexico, Nicaragua, Panama (Edgecombe \& Cupul-Magaña, 2008).

\section{DISCUSSION}

The scutigeromorph fauna of the Dominican Republic is composed of the species Sphendononema guildingii and Dendrothereua linceci with populations that appear to be widely but sparsely distributed from low to high elevations (above 2,000 meters) (Fig. 2). From Haiti only $S$. guildingii is known so far. Two $D$. linceci are reported from the highlands of Sierra de Bahoruco in the 'southern paleoisland' of Hispaniola, which was an independent island with its own biota until docking with the 'northern paleoisland' around the late Miocene ca 10 million years ago (Iturralde Vinent and MacPhee, 1999).

These are the same two species found in Cuba, while a species in Jamaican caves has only been identified as Scutigera sp. No literature records of scutigeromorphs in Puerto Rico have been found, though a photograph of a correctly determined specimen of $S$. guildingii taken at the Maricao State Forest, western Puerto Rico appears on the website on West Indian natural history http://www.kingsnake.com/westindian/ of Alejandro Sánchez. Scutigeromorph centipedes most likely colonized the Caribbean islands from Central and South America early in the archipelago's evolution. Given that there are records from low and small islands like some of the Bahamas, Guana, St. Vincent and Grenada, it would appear that large islands with complex ecosystems are not a requirement for scutigeromorph populations. Therefore scutigeromorphs probably occur in many of the West Indian islands.

Fossil scutigeromorphs in Dominican amber. Amber from the Dominican Republic is famous for the high diversity and exceptional preservation of its fossilized inclusions. The age of the Dominican amber has been the subject of some debate, with earlier studies based on the analysis of associated Foraminifera and nuclear magnetic resonance spectroscopy suggesting a range of up to 40 million years for amber from different mines (reviewed in Poinar, 1992). More recent studies based on paleogeographic and biostratigraphic evidence (Iturralde Vinent and MacPhee, 1996), propose that the Dominican amber was entombed in a single depositional basin during the late Early Miocene through early Middle Miocene (15-20 million years ago) and were never subject to extensive redeposition from older age sediments. Further study allowed the dating to be constrained to around 16 million years old (Burdigalian stage of the Miocene) (Iturralde Vinent, 2001; Penney, 2010).

Several scutigeromorph specimens have been reported as fossilized inclusions in the Miocene amber from the Dominican Republic. Judging from the number of pictures easily encountered of specimens for sale or in the hands of collectors, it appears that scutigeromorphs are not uncommon in the Dominican amber. Their close association with vegetation and tree trunks probably made them likely candidates for entrapment in the liquid resin. One specimen of "house" centipede fossilized in Dominican amber was depicted by Poinar (1992). Photographs of four other specimens appeared in a book by Wu (1997), where one of the pictures is identified as the widespread 'house centipede' Scutigera coleoptrata (Linnaeus, 1758), while the same identification appears intended for the others. However, because $S$. coleoptrata originates in the Mediterranean region, having spread to many parts of the world by anthropogenic introduction in rather recent times, it is very unlikely to be the species fossilized in the Dominican amber. So far, extant specimens of $S$. coleoptrata have never been found in Hispaniola. 


\section{ACKNOWLEDGMENTS}

It is our pleasant duty to acknowledge Dominican biologists Ruth H. Bastardo (Instituto de Investigaciones Botánicas y Zoológicas, Santo Domingo), Sardis Medrano (Instituto de Investigaciones Agrícolas y Forestales) and Brígido Hierro (Departamento de Vida Silvestre, Ministerio de Medio Ambiente, Santo Domingo) for their excellent contributions to the field work of the Hispaniolan Orthopteroids Project NSF DEB-0103042. Stewart B. Peck (Carleton University, Ontario, Canada) supplied information on records from Jamaica. Gabriel de los Santos (MNHNSD) facilitated our access to specimens in their collection. Karolyn Darrow (Department of Entomology, USNM) and Lucrecia H. Rodríguez (Systematic Entomology Lab, USDA) assisted with the production of the plate and distribution map. Our friends at the IIBZ, biologists Ruth H. Bastardo, Santo Navarro, Yira Rodríguez, América Sánchez and Candy Ramírez were helpful hosts during the senior author's latest visit to the Dominican Republic.

\section{LITERATURE CITED}

Bolton, S., N. MacLeod and G. D. Edgecombe. 2009. Geometric approaches to the taxonomic analysis of centipede gonopods (Chilopoda: Scutigeromorpha). Zoological Journal of the Linnean Society, 156: 239-259.

Bonato, L., G. D. Edgecombe and M. Zapparoli. 2011. Chilopoda - Taxonomic overview, pp. 363-443. In: Minelli, A. (ed.), Treatise on Zoology - The Myriapoda, Volume 1. Brill, Leiden.

Chamberlin, R. V. 1918. The Chilopoda and Diplopoda of the West Indies. Bulletin of the Museum of Comparative Zoology, 62: 149-262.

Chamberlin, R. V. 1921. Results of the Bryant Walker expeditions of the University of Michigan to Columbia 1913 and British Guiana 1914. Occasional Papers of the Museum of Zoology, University of Michigan, 97: 1-28.

Edgecombe, G. D. 2007. Centipede systematics: progress and problems. Zootaxa, 1668: 327341.

Edgecombe, G. D. 2011. Chilopoda - The fossil history, p. 355-361. In: Minelli, A. (ed.), Treatise on Zoology - The Myriapoda, Volume 1. Brill, Leiden.

Edgecombe, G. D. and F. G. Cupul-Magaña. 2008. Primer registro de Scutigera linceci (Wood, 1867) para Jalisco y anotaciones sobre los escutigeromorfos de México (Chilopoda: Scutigeromorpha: Scutigeridae). Dugesiana, 15: 17-19.

Edgecombe, G. D. and G. Giribet. 2009. Phylogenetics of scutigeromorph centipedes (Myriapoda: Chilopoda) with implications for species delimitation and historical biogeography of the Australian and New Caledonian faunas. Cladistics, 25: 406-427.

Iturralde Vinent, M. A. 2001. Geology of the amber bearing deposits of the Greater Antilles. Caribbean Journal of Science, 37: 141-167.

Iturralde Vinent, M. A. and R. D. E. MacPhee. 1996. Age and paleogeographical origin of Dominican amber. Science, 273: 1850-1852.

Iturralde Vinent, M. A. and R. D. E. MacPhee. 1999. Paleogeography of the Caribbean region: implications for Cenozoic biogeography. Bulletin of the American Museum of Natural History, 238: 1-95. 
Lazell, J. 2005. Island: Fact and Theory in Nature. University of California Press, Berkeley, $382 \mathrm{pp}$.

Muchmore, W. B. 1993. List of terrestrial invertebrates of St. John, U.S. Virgin Islands (exclusive of Acarina and Insecta), with some records of freshwater species. Caribbean Journal of Science, 29: 30-38.

Peck, S. B. 1992. A synopsis of the invertebrate cave fauna of Jamaica. The National Speleological Society Bulletin, 54: 37-60.

Penney, D. 2010. Dominican amber, pp. 22-41. In: Penney, D. (Ed.) Biodiversity of Fossils in Amber from the Major World Deposits. Siri Scientific Press, Manchester.

Poinar, G. O., Jr. 1992. Life in Amber. Stanford University Press, Stanford, California, 350 pp.

Sánchez, A. Father Sánchez's Web Site of West Indian Natural History. http:www.kingsnake. com/westindian. Accessed August 2012.

Shear, W. A., A. J. Jeram and P. A. Selden. 1998. Centipede legs (Arthropoda, Chilopoda, Scutigeromorpha) from the Silurian and Devonian of Britain and the Devonian of North America. American Museum Novitates, 3231: 1-16.

Stoev, P. and J. J. Geoffroy. 2004. An annotated catalogue of the scutigeromorph centipedes in the collection of the Muséum National d'Histoire Naturelle, Paris (France) (Chilopoda: Scutigeromorpha). Zootaxa, 635: 1-12.

Verhoeff, K. W. 1904. Uber Gattungen der Spinnenasseln (Scutigeriden). Sitzungs-Berichte der Gesellschaft naturforschenden Freunde, Berlin, 1904 (10): 245-285.

Wood, H. C. 1867. Descriptions of new species of Texan Myriapoda. Proceedings of the Academy of Natural Sciences of Philadelphia, 19: 42-44.

Wu, R. J. C. 1997. Secrets of a Lost World: Dominican amber and its Inclusions. Privately published, Santo Domingo, 222 pp.

Würmli, M. 1973. Die Scutigeromorpha (Chilopoda) von Costa Rica. Ueber Dendrothereua arborum Verhoeff, 1944. Studies on Neotropical Fauna and Environment, 8: 75-80.

Würmli, M. 1974. Systematic criteria in the Scutigeromorpha. (pp. 89-98). In: Blower, J. G. (Ed.). Myriapoda. Symposium of the Zoological Society of London, 32.

Würmli, M. 1978. Synopsis der neotropischen Pselliodidae (Chilopoda: Scutigeromorpha). Studies on Neotropical Fauna and Environment, 13: 135-142.

Würmli, M. 2005. Revision der afrikanischen Pselliodiden(Chilopoda: Scutigerida: Pselliodidae). Schubartiana, 1: 3-8.

Würmli, M. and S. Negrea. 1977. Les scutigéromorphes de l'ile de Cuba (Chilopoda: Scutigeromorpha). Fragmenta Faunistica, 23: 75-81.

[Recibido: 06 de febrero, 2013. Aceptado para publicación: 11 de marzo, 2013] 